\title{
Drought Conditions in Utah During 1999-2002: A Historical Perspective
}

\section{Introduction}

"When the well is dry, we learn the worth of water" - Ben Franklin, from Poor Richard's Almanac, 1733

Utah's weather is prone to extremes - from severe flooding to multiyear droughts. Five major floods occurred during 1952, 1965, 1966, 1983 , and 1984, and six multiyear droughts occurred during 1896-1905, 1930-36, 1953-65, 1974-78 (U.S. Geological Survey, 1991), and more recently during 1988-93 and 1999-2002. The areal extent of floods generally is limited in size from one to several watersheds, whereas droughts generally affect most or all of the state. Southern Utah, in particular the Virgin River drainage basin, began experiencing drought conditions during the winter of 1998-99. By 2000 , drought conditions were evident throughout all of Utah. The current drought (1999-2002) is comparable in length and magnitude to previous droughts; however, with population growth and increased demand for water in Utah, the general effect is more severe.

During 2002, the fourth straight year of nearly statewide drought conditions, some areas of Utah experienced record-low streamflows. Several record-low streamflows occurred in streams with records dating back to the 1900s. The U.S. Geological Survey (USGS) uses streamflow data from eight long-term

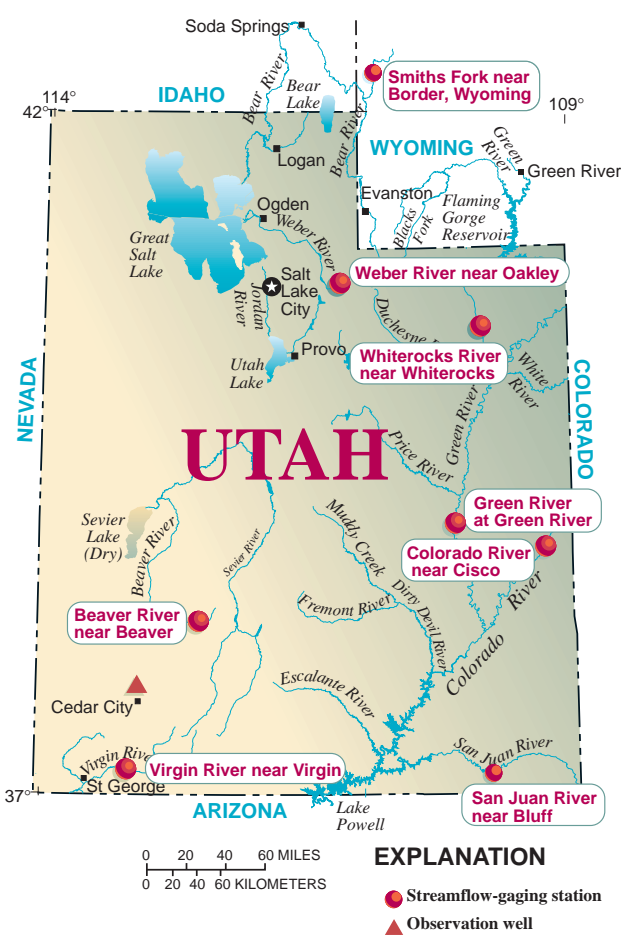

Figure 1. Location map of selected streamflow-gaging stations in Utah and Wyoming.

streamflow-gaging stations for comparison of hydrologic conditions in Utah (fig. 1). Three of these gages registered new record-low annual streamflows for water year 2002 (October 1,
2001, to September 30, 2002): Colorado River near Cisco, San Juan River near Bluff, and Virgin River at Virgin. At two other gages in eastern Utah, Whiterocks River near Whiterocks and Green River near Green River, 2002 was the second driest year on record. Streamflow in the Upper Colorado River Basin has been so low that the water surface of Lake Powell is predicted to be 80 feet below the fill level by January 2003 (Bureau of Reclamation, 2002). The water level of Lake Powell is currently (2003) low enough near Hite Marina (at the upstream end of the lake) that much of the riverbed of the Colorado and Dirty Devil Rivers is exposed, as are the deltaic sediments that have been deposited since the lake began filling in 1963 (fig. 2).

The adjacent states of Colorado, Arizona, and New Mexico also have been experiencing extreme drought conditions and the negative impacts that result. Record-sized forest fires during the summer of 2002 in Arizona and Colorado were directly related to the extremely dry conditions.

\section{Precipitation}

Precipitation directly affects streamflow. Under normal precipitation conditions, Utah receives less precipitation than every other state except Nevada. Average annual precipitation at Salt Lake City is about 16.5 inches, and precipitation statewide ranges from about 5

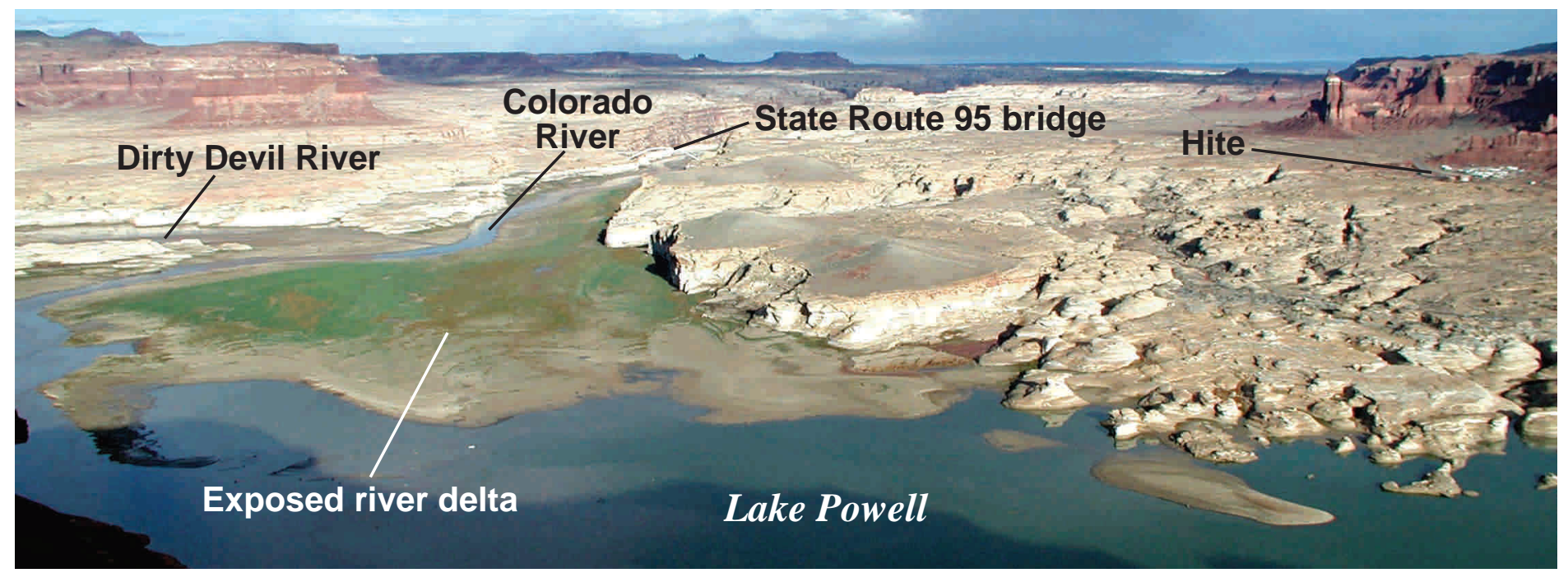

Figure 2. Lake Powell near Hite, Utah, showing exposed channel of the Colorado and Dirty Devil Rivers, which are normally flooded by the lake, as well as the deltaic sediments that are deposited at the upper end of the lake; view to east in October 2002. 


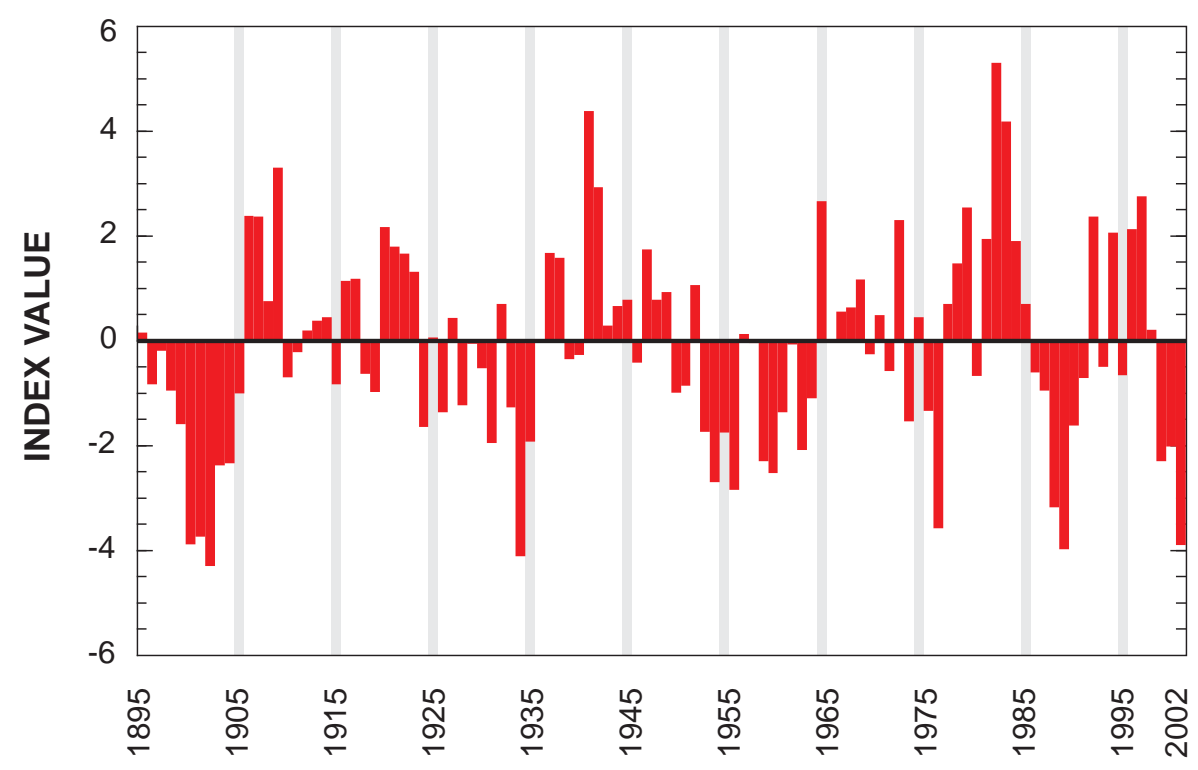

Figure 3. Palmer Drought Severity Index for Utah, 1895-2002.

inches on the Great Salt Lake Desert to about 60 inches in the highest mountains (Butler and Marsell, 1972). Three types of moistureproducing weather systems generally account for most precipitation in Utah: Pacific frontal systems, dissipating tropical storms, and summer pressure ridges can dominate over the Western United States and push storm systems northward. These persistent high-pressure ridges result in decreased snowfall in Utah mountain ranges (U.S. Geological Survey, 1991). Mountain snowpacks have generally been below normal statewide since the winter of 1998-99, and Utah has experienced significant reductions in spring runoff since 2000.

Many Federal and State government agencies use the Palmer Drought Severity Index (PDSI) to classify and assess long-term meteorological droughts (Hayes, 2002). The PDSI drought index responds to abnormally wet or dry weather conditions and classifies the conditions on a scale from -6 to 6 . On this scale, -4.0 or less signifies extreme drought conditions and 4.0 or more signifies extremely wet conditions. Summarized data from the Utah State University Climate Center in Logan, Utah (Donald Jensen, written commun., 2002), illustrates the variable nature of precipitation in Utah (fig. 3). On the basis of the PDSI classification scale, the droughts of 1988-93 and 1999-2002 are severe to extreme, but conditions are not as dry as those during 1896-1905 (fig. $3)$.
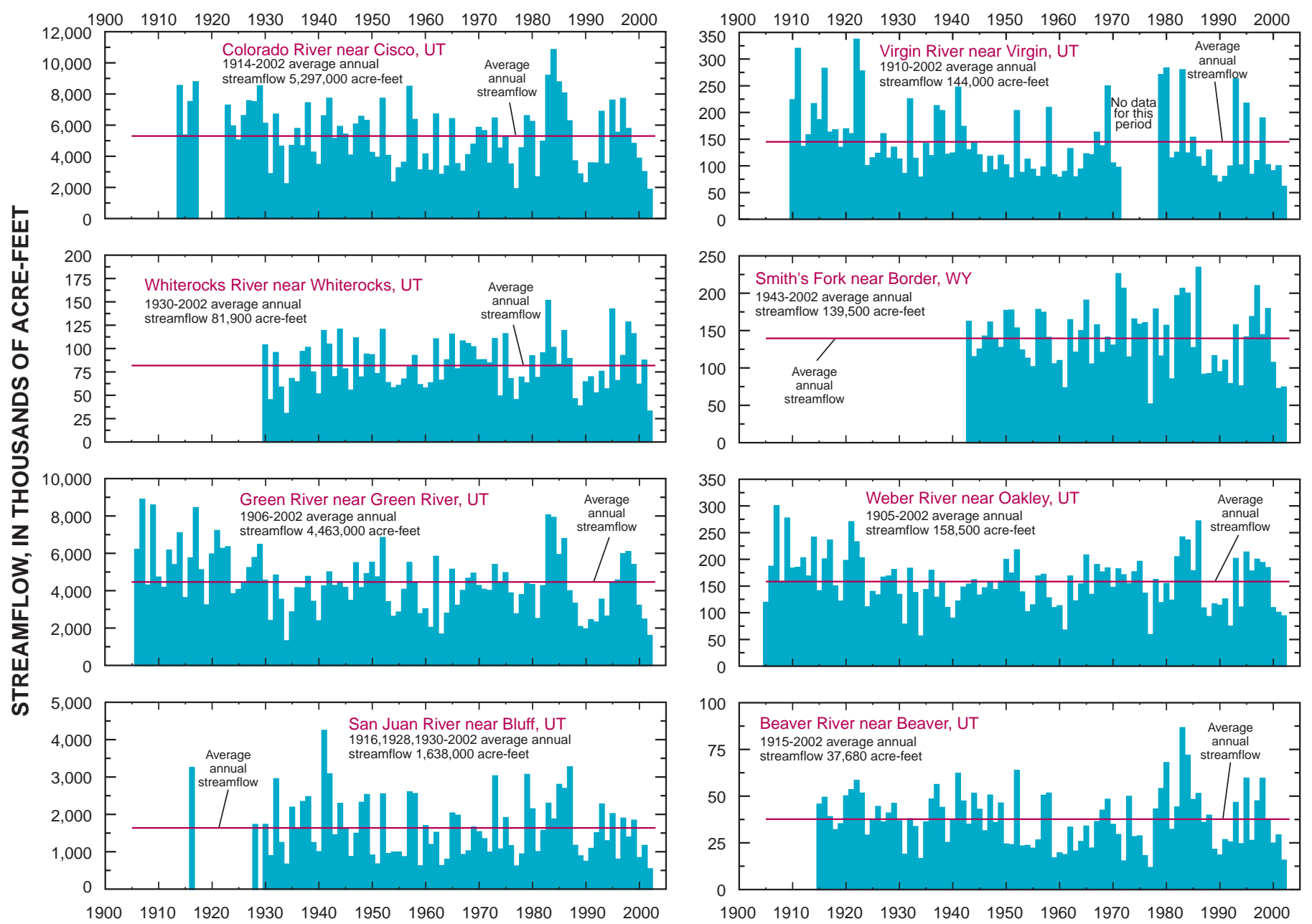

Figure 4. Relation of annual streamflow to average annual streamflow for the period of record. 
Table 1. Chronology of major and other memorable floods and droughts in Utah, 1884-2002

\section{Flood or \\ drought}

Flood

Drought

Flood

Drought

Flood

Drought

Flood

Flood

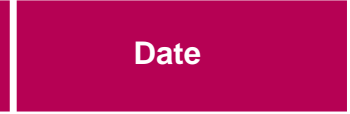

July 4, 1884

1896-1907

Aug. 13, 1923

1930-36

Apr. 28-June 11, 1952

1953-65

June 16, 1963

June 10-11, 1965

Flood

Dec. 6-7, 1966

Flood

Flood

Sept. 5-7, 1970

Flood

Drought

Flood

Aug. 27, 1972

1974-78

Apr. 10-June 25, 1983

Flood

Apr. 17-June 20, 1984

Flood

May 22, 1984

Flood

June 15, 1984

June 3, 1986

Flood

June 7, 1986

Drought

Flood

Flood

Flood

Feb.-Mar. 1995

May 1997

Drought

1999-present

\section{Area affected}

Colorado River

Statewide

Tributaries to Great Salt Lake between Ogden and Salt Lake City

Statewide

Strawberry, upper Price, upper San Rafael, Ogden, Weber Provo, and Jordan Rivers; Blacksmith and Spanish Fork; upper Muddy and Chalk Creeks

Statewide

Duchesne River

Ashley Creek and other streams between Manila and Vernal, and west of Manila

Virgin and Santa Clara Rivers

Cottonwood Wash and other nearby tributaries to San Juan River

San Juan River and tributaries from McElmo Creek to Chinle Creek

Vernon Creek

Statewide

Lower Duchesne and Jordan Rivers and tributaries (including Spanish Fork); upper Price, Bear, Sevier, and San Pitch Rivers; Chalk, East Canyon, Trout, and George Creeks; Great Salt Lake and tributaries between Ogden and Salt Lake City

White, upper Price, and Fremont Rivers; lower Bear and Sevier Rivers and tributaries; Beaver River; Red Butte Creek; Spanish Fork; Jordan River

Sevier Lake

Utah Lake

Great Salt Lake

Provo River

Statewide

Quail Creek, lower Virgin River

Santa Clara River

South Fork Ogden River, Logan River, Blacksmith's Fork

Statewide

\section{Remarks}

Probably snowmelt combined with rainfall.

Regional.

Locally intense thunderstorms. Deaths, 7; damage, $\$ 300,000$.

Regional.

Melting of snowpack having maximum-of-record water content for Apr. 1. Disaster declared. Deaths, 2; damage, $\$ 8.4$ million.

Regional.

Dam failure

Three days of intense rainfall on thick snowpack above altitude of 9,200 feet. Deaths, 7; damage, $\$ 814,000$.

Four days of light to intense rainfall of as much as 12 inches. Damage, \$1.4 million.

Locally intense thunderstorms following 11 days of rainfall. Damage, $\$ 34,000$.

Record-breaking rainfall. Deaths, 2; damage, $\$ 700,000$.

Locally intense thunderstorms.

Regional.

Rapid melting of snowpack having maximum-of-record water content for June 1. Result of large El Niño event. Disaster declared by President. Damage, \$621 million.

Runoff from greater-than-average snowpack for Apr. 1 and spring precipitation. Result of large El Niño event.

Runoff in Sevier River from Nov. 1982 through June 1984 exceeded upstream reservoir capacity; about 1.5 million acre-feet of water conveyed to Sevier Lake. On May 22, 1984 , lake reported to be as deep as 35 feet deep after being dry or nearly dry since about 1880 .

Runoff from greater-than-normal precipitation since Sept. 1982 increased lake level to 101 -year record of 5.46 feet above compromise level on June 15, 1984. Mainly a result of large El Niño event of 1983-84. Damage, \$5.9 million.

High runoff from greater-than-normal precipitation since Sept., 1982 increased lake level to 140 -year record altitude of 4,211.85 feet on June 3, 1986. Partially a result of large El Niño event of 1983-84. Damage, \$268 million.

Trial Lake dam failure. Slope-area measurement.

Regional.

Quail Creek Reservoir dike failed on Jan. 1, 1989, releasing about 25,000 acre-feet of water to the Virgin River near Hurricane. Damage, \$12 million.

Greater-than-normal snowpack in the Bear and Weber River drainage basins caused minor flooding. Minor damage occurred to cabins and campgrounds in the area.

Regional. 


\section{Streamflow}

Data from eight long-term streamflowgaging stations maintained by the USGS Utah District were used to assess historic and current drought conditions. The stations (fig. 1) were selected from a network of more than 150 stations in Utah and are considered index sites because they generally reflect streamflow conditions in their local area. Major dams have regulated flow on the Colorado, Green, and San Juan Rivers upstream from the index sites since the early 1960s. The Beaver, Virgin, and Weber Rivers are lightly regulated by small headwater reservoirs or power generating facilities. Smith's Fork and the Whiterocks River have small diversions in upper watershed areas but are not regulated upstream from the gages. Despite these modifications to the drainages, these index sites are considered to generally reflect hydrologic conditions in their respective watersheds, including snowpack and the amount of water stored in reservoirs.

\section{Historic Streamflow Data}

A chronology of significant floods and droughts in Utah from 1884 to 2002 and a summary of their effects on infrastructure, population, and the environment is presented in table 1. Prior to current drought conditions, Utah experienced drought on a regional scale most recently in the late 1980 s to early 1990 s. Other major droughts occurred during 18961905, 1930-36, 1953-65, and 1974-78. The average length of these droughts is about 5 years and they recur about every 10 to 20 years.

A hydrologic drought is defined as "a period of below average water content in streams, reservoirs, ground-water aquifers, lakes and soils" (Yevjevich and others, 1977). The relation of annual streamflow to average annual streamflow for the period of record for the eight index sites (fig. 4) shows the cyclical nature of wet and dry conditions in Utah.

10/1/1998 4/1/1999 10/1/1999 4/1/2000 10/1/2000 4/1/2001 10/1/2001 4/1/2002 10/1/2002

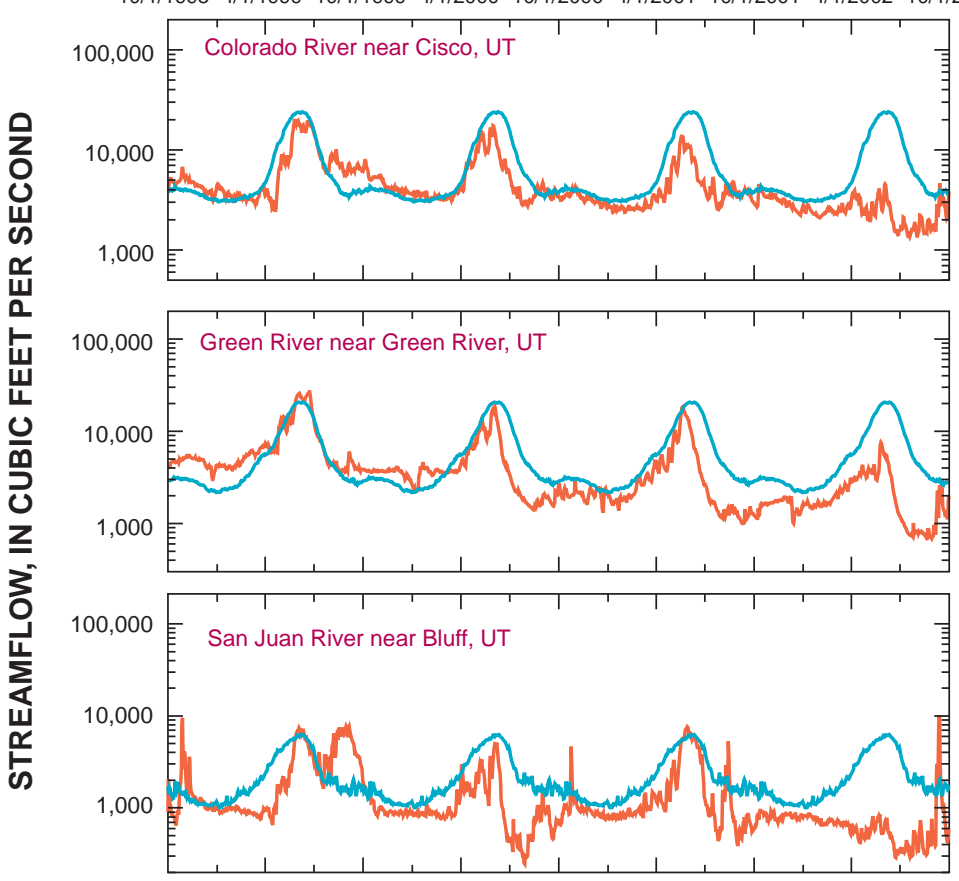

10/1/1998 4/1/1999 10/1/1999 4/1/2000 10/1/2000 4/1/2001 10/1/2001 4/1/2002 10/1/2002

EXPLANATION

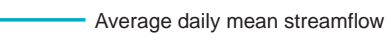

Figure 5. Relation of daily mean streamflow for water years 1999-2002 to mean streamflow for period of record.

\section{Current Streamflow Data}

The end-of-season snowpack, as measured by the Natural Resources Conservation Service SNOTEL system on April 1, 2002, was below average statewide. The snowpack, and therefore the relative amount of water available for runoff, was about 78 percent of average in northern Utah drainages and ranged from 24 percent to 54 percent of average in the southern part of the State. In eastern and southeastern Utah, the endof-season snowpack was the lowest since 1977 and 1999 (Natural Resources Conservation Service, 2002).

The percentage of average flow for the eight index sites for 1999-2002 is shown in table
2. In 1999, streamflow was near or below average for the Colorado River, Beaver River, and Virgin River. These streamflow-gaging stations are all located in southern Utah. By 2000, all of the index sites indicated below-average flow. This trend has continued through 2002 with the exception of the Whiterocks River, which had slightly higher-than-average flow in 2001. The Whiterocks River flows down the southern slope of the Uinta Mountains in northeastern Utah (fig. 1). This area accumulated average snowpack during the winter of 2001 (Natural Resources Conservation Service, 2002); however, on average, the larger Green River basin accumulated a substantially lower-thanaverage snowpack for the same period as

Table 2. Annual streamflow data for eight long-term streamflow-gaging stations

[kac-ft, thousands of acre-feet]

\begin{tabular}{|c|c|c|c|c|c|c|c|c|c|c|c|}
\hline \multirow[b]{2}{*}{ Station Name } & \multirow[b]{2}{*}{$\begin{array}{l}\text { Period of } \\
\text { record }\end{array}$} & \multirow{2}{*}{$\begin{array}{l}\text { Average } \\
\text { total } \\
\text { annual } \\
\text { flow for } \\
\text { period of } \\
\text { record } \\
\text { (kac-ft) }\end{array}$} & \multicolumn{2}{|c|}{1999} & \multicolumn{2}{|c|}{2000} & \multicolumn{2}{|c|}{2001} & \multicolumn{2}{|c|}{2002} & \multirow{2}{*}{$\begin{array}{c}\text { Rank of } \\
\text { lowest } \\
\text { total } \\
\text { annual } \\
\text { flow, } \\
2002\end{array}$} \\
\hline & & & $\begin{array}{c}\text { Total } \\
\text { annual } \\
\text { flow } \\
\text { (kac-ft) }\end{array}$ & $\begin{array}{c}\text { Percent } \\
\text { of } \\
\text { average }\end{array}$ & $\begin{array}{c}\text { Total } \\
\text { annual } \\
\text { flow } \\
\text { (kac-ft) }\end{array}$ & $\begin{array}{c}\text { Percent } \\
\text { of } \\
\text { average }\end{array}$ & $\begin{array}{c}\text { Total } \\
\text { annual } \\
\text { flow } \\
\text { (kac-ft) }\end{array}$ & $\begin{array}{c}\text { Percent } \\
\text { of } \\
\text { average }\end{array}$ & $\begin{array}{c}\text { Total } \\
\text { annual } \\
\text { flow } \\
\text { (kac-ft) }\end{array}$ & $\begin{array}{c}\text { Percent } \\
\text { of } \\
\text { average }\end{array}$ & \\
\hline Colorado River near Cisco, UT & 1914-2002 & 5,297 & 4,807 & 90 & 3,856 & 72 & 3,003 & 56 & 1,856 & 35 & 1 \\
\hline Whiterocks River near Whiterocks, UT & 1930-2002 & 82 & 116 & 140 & 62 & 75 & 87 & 106 & 33 & 40 & 2 \\
\hline Green River near Green River, UT & $1906-2002$ & 4,463 & 5,392 & 120 & 3,206 & 71 & 2,464 & 55 & 1,591 & 36 & 2 \\
\hline San Juan River near Bluff, UT & $1916,1928,1930-2002$ & 1,638 & 1,837 & 111 & 838 & 51 & 1161 & 70 & 538 & 33 & 1 \\
\hline Virgin River near Virgin, UT & $1910-2002$ & 1,44 & 102 & 70 & 90 & 62 & 100 & 69 & 61 & 43 & 1 \\
\hline Smiths Fork near Border, WY & $1943-2002$ & 139 & 179 & 127 & 107 & 76 & 72 & 51 & 74 & 53 & 4 \\
\hline Weber River near Oakley, UT & 1905-2002 & 158 & 184 & 116 & 109 & 69 & 100 & 63 & 93 & 59 & 8 \\
\hline Beaver River near Beaver, UT & 1915-2002 & 38 & 37 & 97 & 25 & 65 & 29 & 77 & 16 & 41 & 3 \\
\hline
\end{tabular}



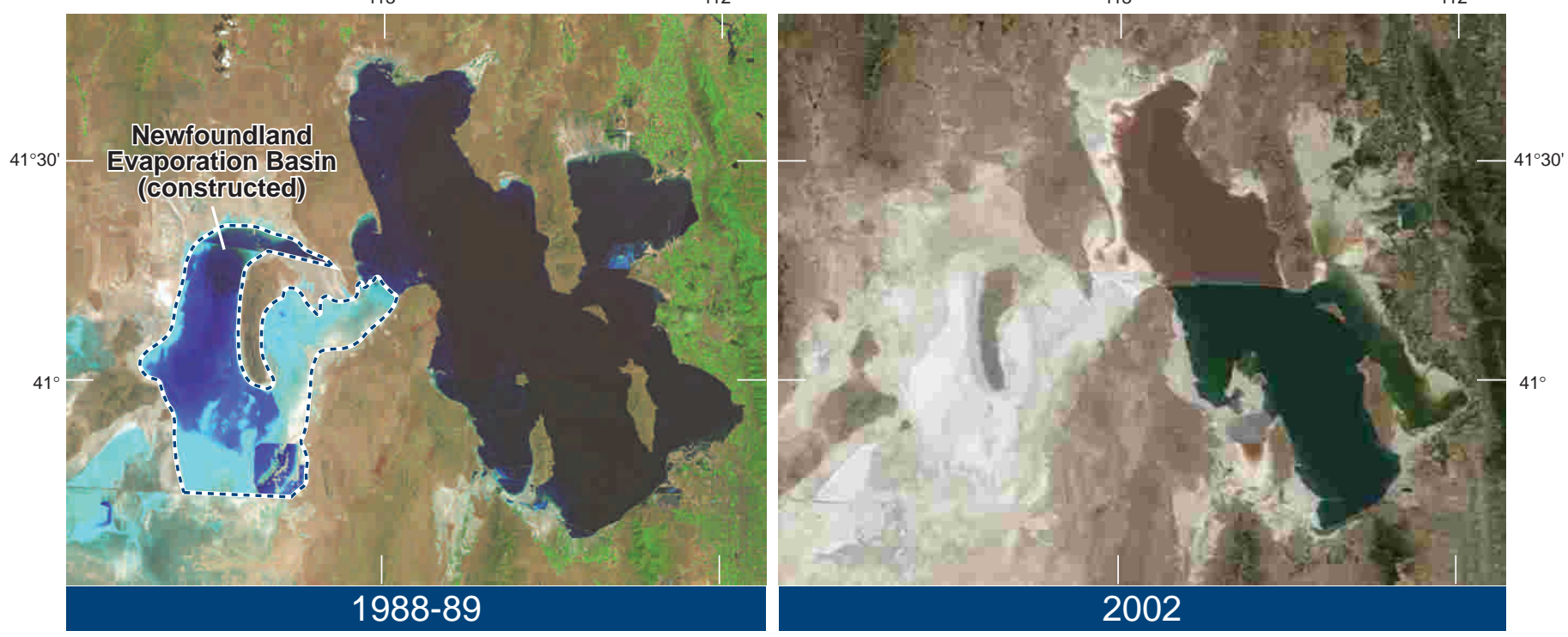

Figure 6. Comparison of satellite images of Great Salt Lake, 1988-89 and 2002.

evidenced by the Green River near Green River, UT, station (fig. 4 and table 2). Total annual flow for water year 2002 is ranked in table 2 . The lowest total annual flow on record at the Colorado River near Cisco, San Juan River near Bluff, and Virgin River at Virgin stations occurred during 2002, as did the second lowest total annual flow on record at the Whiterocks River and Green River stations. The 2002 drought was not as severe at the northern stations; however, 2002 was still one of the 10 driest years on record for Smiths Fork and the Weber and Beaver Rivers.

\section{Effects of the Drought}

\section{Effects on Selected Reservoirs and Great Salt Lake}

The compounded effects of 3 years of lessthan-normal precipitation include lowered water levels of most major reservoirs in Utah. Releases from dams on these reservoirs have been, and most likely will continue to be, the minimum releases required for downstream water users. The level of Flaming Gorge Reservoir has dropped by about 18 feet from its level during years with average runoff. Recovery from this deficit is expected to take about 2 years, assuming that inflows return to normal by spring 2003 (Bureau of Reclamation, 2002).

According to the Bureau of Reclamation, unregulated inflow to Lake Powell during water year 2002 was only 3.06 million acre-feet, or 25 percent of the 30 -year average, which is the least amount of inflow to Lake Powell since the completion of Glen Canyon Dam in 1963 (Bureau of Reclamation, 2002). Average streamflow conditions during the past 4 years in relation to historic maximum and minimum flows at the Colorado River, Green River, and
San Juan River gaging stations are shown in figure 5. These three rivers are the major inflows to Lake Powell, and peak runoff typically occurs during May and June from snowmelt in the mountain headwaters. All three stations recorded streamflow near the historic mean during water year 1999 as compared to 2002, when streamflow at all three stations was at or near the historic minimum. Essentially no spring peak runoff for the Colorado River or San Juan River occurred during 2002. After the spring runoff, summer base-flow conditions also declined steadily (fig. 5). Lake Powell was filled to about 58 percent of capacity as of November 2002.

Because Great Salt Lake is a terminal lake with no outlet to the sea, the water level fluctuates continuously in response to climatic factors. As surface-water inflows to the lake decreased during 1999-2002, lake levels declined. The water-surface altitude of Great Salt Lake during November 2002 was about 4,197 feet, which is slightly lower than the minimum altitude during the 1974-78 and 1988-93 droughts. Since 1847 when record keeping began, the lake has been lower than its current level only three times: during approximately 1903-07, 1933-50, and 1956-72 (Herbert and others, 2001). The current level is about 6 feet above the historic low of 4,191.35 feet recorded during the fall of 1963 and about 14 feet below the historic high of 4,211.6 feet recorded June 3, 1986. Recent satellite imagery of Great Salt Lake shows the 2002 light-colored exposed shoreline in comparison with an image obtained during 198889 when the water level was 8 to 10 feet higher (water-surface altitude of 4,205 to 4,207 feet, fig. 6).

\section{Effects on Ground Water}

Prolonged droughts have a primary and secondary effect on ground-water resources. First, decreased precipitation leads to decreased recharge to aquifers. Second, decreased surfacewater resources generally lead to increased ground-water withdrawals, as well as to increased requests for water-well construction permits (Gates and Allen, 1996).

Aquifers in arid to semiarid regions are typically recharged from higher-altitude areas that receive more precipitation. Decreased precipitation and snowpack runoff in these areas leads to a decrease in aquifer recharge. In addition, dry conditions deplete soil moisture. This moisture needs to be replaced before recharge conditions can return to normal. Aquifers also can be recharged by seepage from lakes and streams. As these surface-water sources of recharge dry up during a drought, recharge to aquifers is again decreased.

As surface-water sources diminish during a drought, irrigators and public-supply systems withdraw more ground water. During the droughts of 1974-77 and 1988-93, the number of well permits granted rose sharply (Gates and Allen, 1996). This increased demand for ground water increased the stress on an already depleted aquifer. In general, ground-water levels in Utah have declined during the current drought years (Burden and others, 2002). The correlation between droughts and low water levels is shown in a well in Cedar Valley, near Cedar City, Utah (fig. 7). Lower ground-water levels are the result of both decreased recharge and increased withdrawals; however, it is difficult to determine which causes the greater effect. 


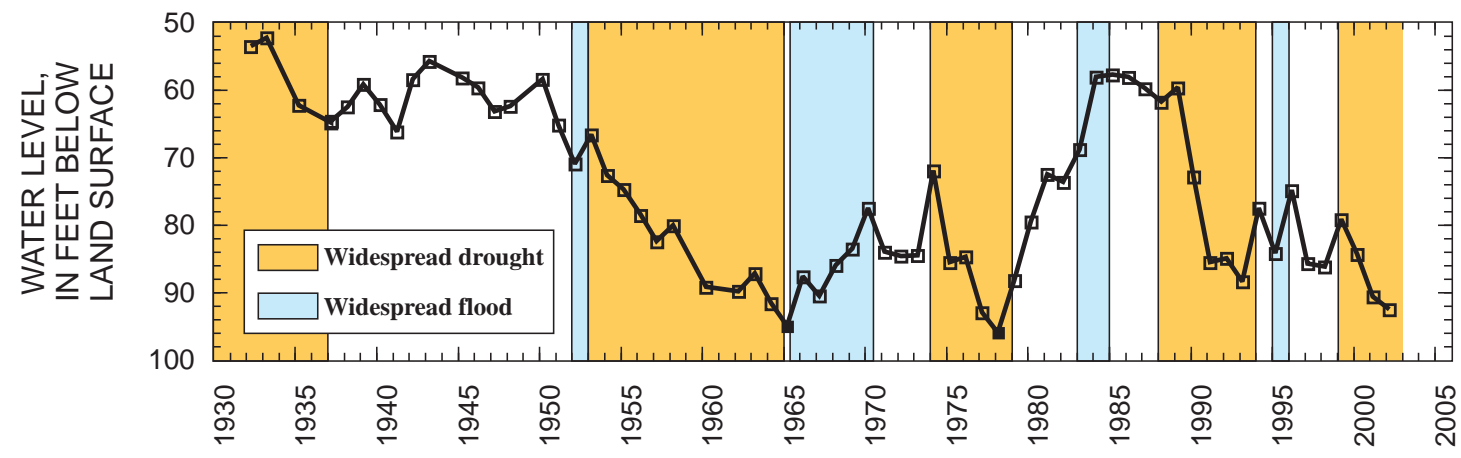

Figure 7. Water levels in a well near Cedar City, Utah.

\section{Summary and Conclusions}

Utah has experienced drought conditions statewide for the past 3 water years, and in the southern part of the state for the past 4 water years. In general, the drought has been more severe in the southern parts of the state. Total annual flow during water year 2002 at the Colorado River near Cisco, Green River near Green River, Virgin River near Virgin, and the San Juan River near Bluff, was the lowest recorded during approximately the past 100 years of record. During water year 2002, streamflow conditions at streamflow-gaging stations in southern Utah showed little to no effect from spring runoff and approached or exceeded the historic minimum flows.

Decreased flow from major rivers in Utah has led to a decline in most reservoir levels and in Great Salt Lake. Drought conditions in Utah are common and normally last an average of about 4 years. The current drought is not unusual for its length but rather for its severity, as water year 2002 will be recorded as one of the driest years on record for many parts of Utah.

\section{U.S. Geological Survey Streamflow- Monitoring Program}

For more than 100 years, the USGS has been collecting water data in Utah with support from Federal, State, and local cooperators. The USGS investigates the occurrence, quantity, quality, and movement of surface and ground water and disseminates the data to the public and to Federal, State, and local agencies and governments involved with managing the water resources of Utah. In cooperation with the State of Utah, the USGS measures water levels on a yearly basis in more than 1,000 water wells throughout Utah. The USGS also operates more than 150 streamflow-gaging stations in Utah. Real-time data from most of these stations are available on the Utah District website at http://ut.water.usgs.gov or from the National USGS website at http://waterdata.usgs.gov/ut/nwis.
For more information contact:

U.S. Geological Survey

2329 West Orton Circle

Salt Lake City, UT 84119

801.908 .5000

http://ut.water.usgs.gov

By Chris D. Wilkowske, David V. Allen, and Jeff V. Phillips

\section{References}

Burden, C.B., and others, 2002, Groundwater conditions in Utah, Spring of 2002: Utah Division of Water Resources Cooperative Investigations Report No. 43, 120 p.

Bureau of Reclamation, 2002, Upper Colorado Region Water Resources Information Center, accessed November 27, 2002, at http://www.uc.usbr.gov/wrg/index.html

Butler, E., and Marsell, R.E., 1972, Cloudburst floods in Utah, 1939-69: Utah Division of Water Resources Cooperative Investigations Report 11, 103 p.

Gates, J.S., and Allen, D.V., 1996, Groundwater development in Utah and effects on ground-water levels and chemical quality, Utah Department of Natural Resources Cooperative Investigations Report 37, 19 p.

Hayes, M.J., 2002, Drought indices, in What is Drought?: National Drought Mitigation Center, University of Nebraska, Lincoln, accessed September 26, 2002, at http://www.drought.uni.edu/whatis/indices.html

Herbert, L.R., Wilberg, D.E., and Tibbetts, J.R., 2001, Water resources data, Utah, water year 2001, U.S. Geological Survey Water-Data Report UT-01-1, 440 p.
Natural Resources Conservation Service, 2002, National Water and Climate Center SNOTEL data, accessed January 2, 2003, at http://www.wcc.nrcs.usda.gov/water/ w_data.html

U.S. Geological Survey, 1991, National water summary, 1988-89: U.S. Geological Survey Water-Supply Paper 2375, 591 p.

Yevjevich, V., Hall, W.A., and Salas, J.D. eds., 1977, Drought research needs, in Proceedings of the Conference on Drought Research Needs, December 12-15, 1977: Colorado State University, Fort Collins, Colorado, 276 p., accessed January 17, 2003, at http://md.usgs.gov/drought/define.html 